\title{
Nanoparticular Drug Delivery of Andrographolide isolated from Andrographis Paniculata for its Antithrombotic and Thrombolytic Activity
}

\author{
Manavalan $\mathbf{R}^{*}$ \\ Department of Pharmaceutics, RVS College of Pharmaceutical Sciences, India
}

*Corresponding author: R. Manavalan Rajappan Nadar, Department of Pharmaceutics, RVS College of Pharmaceutical Sciences, Sulur, Coimbatore, TamilNadu, India

Submission: 眥 October 04, 2017; Published: 苜 March 12, 2018

\section{Biography}

Dr. R. Manavaln completed his Ph. D at the age of 28 years from Birla Institute of Technology and Science (BITS Pilani) Rajasthan, India. He is the Professor and Research Director at RVS College of Pharmaceutical Sciences, Sulur, Coimbatore, Tamil Nadu which is a premier pharmacy school caters PG and Doctoral programme in pharmacy. He has published more than 150 research papers in reputed journals. He has produced $33 \mathrm{Ph}$. D's in pharmacy.

The main objective of the present study was to prepare nanoparticles of andro grapholide and comparing with plain and grapholide for testing antithrombotic and thrombolytic activities in animal model. No scientific study was made so far with nanoparticular andro grapholide for the above activities, the aerial parts of the plant Andrographis paniculata were collected and the presence of andrographolide is confirmed by colour test. Extraction of Andrographis paniculata was carried out by cold maceration method, using methanol and dichloromethane (1:1) as a solvent and andrographolide was isolated. The following parameter melting point, UV maximum absorbance, FT-IR and NMR analysis were performed which revealed that the isolated compound was andrographolide.
Oral acute toxicity was carried out as per Indian OECD guidelines 423 by using mice as an animal model. A $2000 \mathrm{mg} / \mathrm{kg}$ body weight of animal dose is administered for acute toxicity study. The antithrombotic activity was carried out in rat model. Bleeding time, clotting time and prothrombin time were determined for antithrombotic activity. The formulated nanoparticle with Eudragit S 100 polymer were evaluated for particle size, particle charge, surface morphology, drug entrapment and drug release. The particle size and entrapment efficiency found to be $189.2 \mathrm{~nm}$ and $72.26 \%$.

The optimized nanoparticles were evaluated for both antithrombotic and thrombolytic activities and compared the activities with plain andrographolide formulation. The antithrombotic activity of nanoparticles, the survival percentage of animals was found to be $39 \%$ increased when compared to andrographolide formulation. Pharmacokinetic study was carried out in which $\mathrm{C}_{\max } \mathrm{T}_{\max }$, AUC, $\mathrm{t}_{1 / 2}$ and MRT were significantly increased with nanaparticles of andrographolide formulation compared with plain andrographolide formulations.
Creative Commons Attribution 4.0 International License

For possible submissions Click Here

\section{Submit Article}

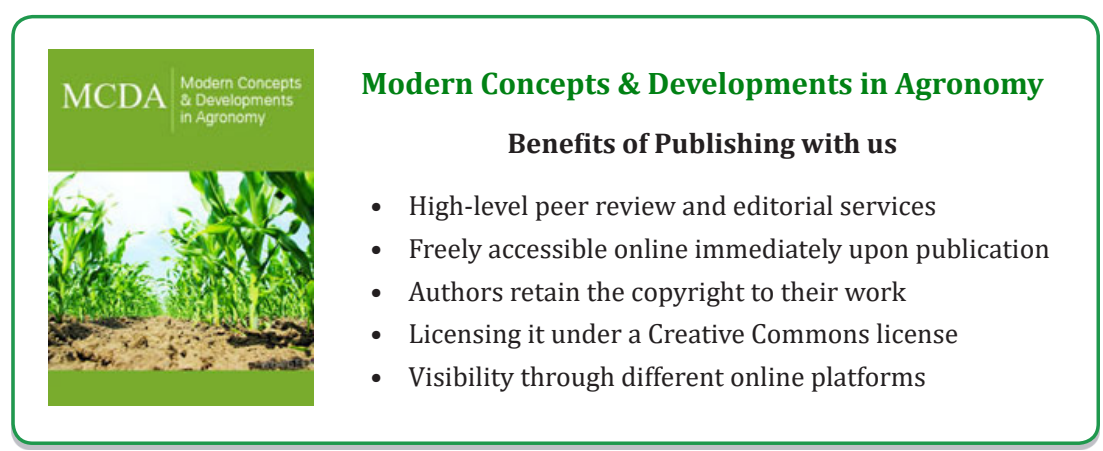

